超重量放水口ケーソンの海上設置

Establishment of a huge caisson-type discharged-opening on the Sea

一川越火力発電所 4 号系列放水口の建設一

-Construction of the discharged-opening, the 4th unit of Kawagoe thermal power station-

\author{
阿知波 文夫* ・森 勝政 ${ }^{* *}$ ・高橋 正 $^{* *}$ \\ Fumio Achiwa , Katsumasa Mori , Tadashi Takahashi
}

The discharged-opening of the 4 th unit of Kawagoe thermal power station is constructed to drain the used water from generator into $2.6 \mathrm{~km}$ away from the coastal in $44 \mathrm{~m}^{3} / \mathrm{sec}$ (see Fig-1). The depth of the sea where the cassion is constructed is about $11.2 \mathrm{~m}$, so the pneumatic caisson method is adopted in the construction on account of the advantage of the method both in economics and construction term. In this method, the blade part of $\mathrm{RC}-$ caisson $(H=16.3 \mathrm{~m})$ is constructed on the land, lifted up and towed by the floating crane, and established at the point. After all equipments are set up, the discharged opening is sunk and constructed with pneumatic cassion method. The total weight of the blade part of cassion is about 3,200tf, so the technical processes for positioning of the cassion, are reported in the paper. Ne believe that this report should be a good reference for the development of the same kind of construction method in the future.

Keywords : RC-caisson, discharged-opening, the 4 th unit of Kawagoe thermal power station

\title{
1.はじめに
}

川越火力発電所 4 号系列の放水口は、同系列で使用する冷却水 $44 \mathrm{~m}^{3} /$ 秒を発電所より約 $2.6 \mathrm{k} \mathrm{m}$ 離れた

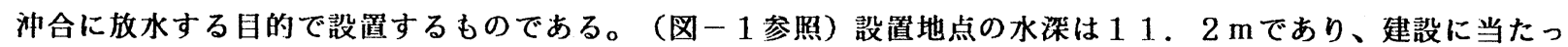
て築島方式連壁工法、オープンケーソン工法などの比較から、経済性、工期などに優れるニューマチックケーソ ン工法を選択した。このう法は、陸上製作のケーソン刃口部をクレーン船で吊上げ曳航して所定の海域に設置し、 ニューマチックケーソン工法で沈設していくもので、総重量約 $3 ， 200 \mathrm{t}$ の R C 製ケーソン（刃口部）据付に 関する諸検討、計湖結果など、今後さらに巨大化し発展する同種工事の参考となる事例が得られたのでここに報 告する。

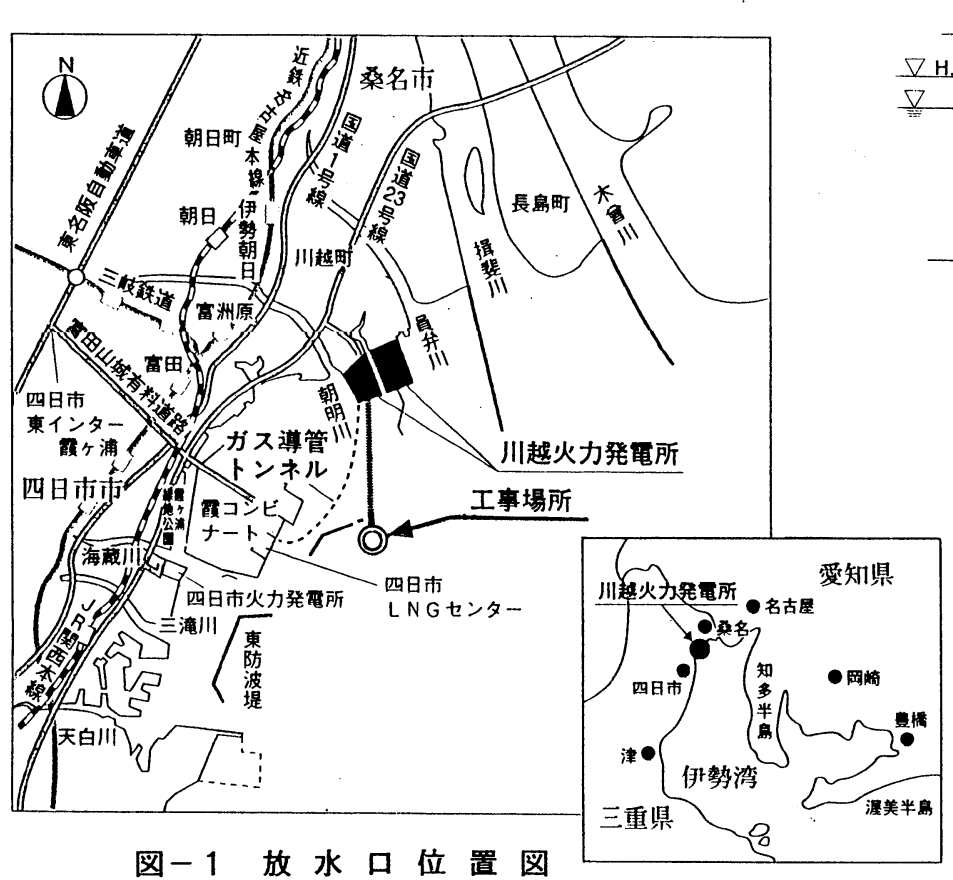

図-1 放 水口位置図

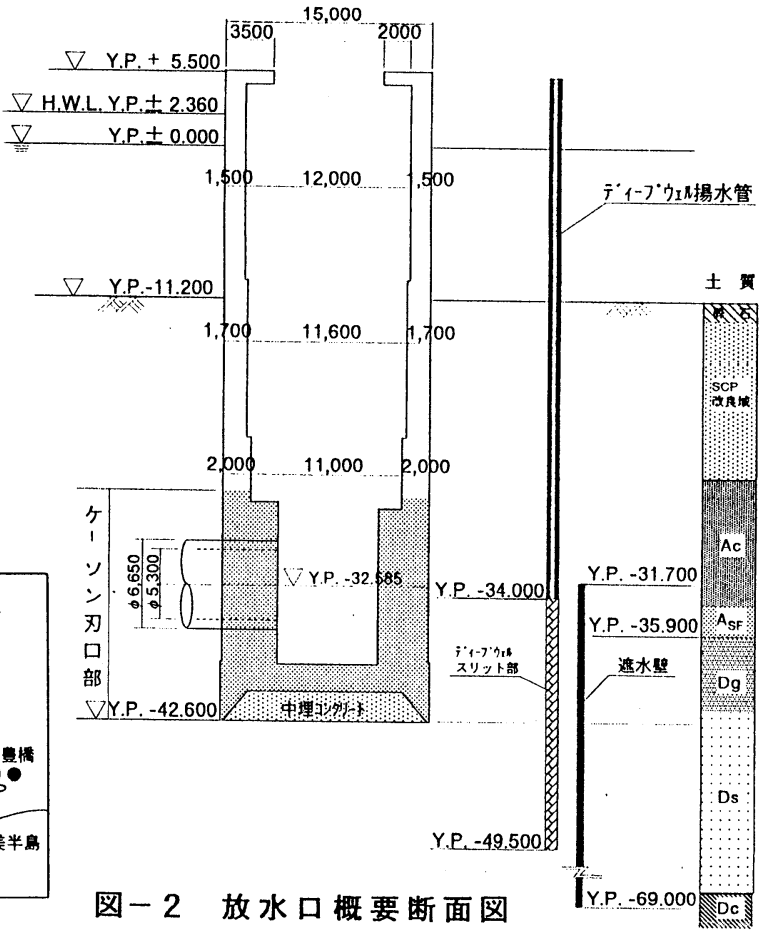

図一 2 放水口概要断面図

\footnotetext{
*フェロー 工博 中部電力（株）川越火力建設事務所（テ512 三重県三重郡川越町大字亀崎新田）

**正会員中部電力（株）川越火力建設事務所士木課
} 


\section{2. 工事概要}

外径 $\phi 15.0 \mathrm{~m} \times$ 全高 $48.1 \mathrm{~m}$ の放水口（図一 2参照）構築に当たって、刃口を含む全高の $1 / 3$ （約 3 , $200 \mathrm{t}$ ）を陸上で製作し、4，100 t 吊フローティングクレーンで吊史航し、所定の海域に設置した後、 ニューマチックケーソン工法で構筑する方法を採用した。ケーソン据付に際しては、据付地盤が $\mathrm{N}$ 值 0 の軟弱な 沖積粘土層であるため、初期の異常沈下の防止に対してサンドコンパクションパイルおよび研石置換による地盤 改良により対処した。吊曳航に対しては、超重量物であるため事前に吊治具の構造検討や、吊上げ時の躯体応力 解析を 3 次元有限要素法により行うとともに、吊上げ時に吊治具および治具周辺のコンクリート応力を計測監視

して施工時の安全性を確認した。

またケーソン沈設時は、掘削最深部 (YP. - 42.6m) の地盤が洪積の砂绦および砂の透水層で、約 $4.5 \mathrm{kgf} / \mathrm{cm}^{2}$ の理倫水圧が作用することから、作業性の確保のため函内気圧を低減する目的で、ケーソンを囲む形の遮水壁と ティープウェルによる揚水とを組合わせた減圧対策を実施した。

\section{3 . 検討内容}

3 . 1 放水口の設置位置

川越火力発電所 4 号系列放水口の設置位置は、発電所付近の閉鎖的な海域環境を目慮して、現在運転中の 1 3 号放水口と分離し、霞ヶ浦防波堤の外侧で発電所用地前面から約 $2.6 \mathrm{k} \mathrm{m}$ 沖合とした。

3.2 放水口工法選択

放水口立坑の施工にあたっては、下記の条件があった。

(1)シールドトンネルの到達立坑のため、ケーソン沈設樑さが $40 \mathrm{~m}$ 以上必要である。

(2)放水口設置位置の水深は $11.2 \mathrm{~m}$ と樑く、また防波堤の外倒に位置し、風波等気象条件の影響が大きい。 (3)地盤は図-2に示すように、海底から深さ約 $25 \mathrm{~m}$ まで嗼弱な蠩層（ $\mathrm{N}$ 值 $=0$ ）であり、その下は洪積層 となっている。

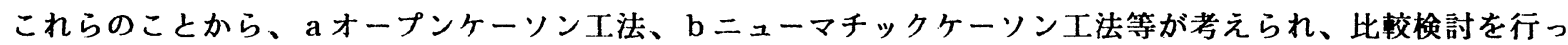
たが、トンネル貫入口を正確な位置に設置する精度や、海域の海洋污渪等、総合的に判断しニューマチックケー ソン工法を選択した。

ケーソン刃ロ部はニューマチックケーソンを施工するにあたって、水深以上の高さまで製作する必要があり、 高さ $16 \mathrm{~m}$ とした。ケーソン本体は制製、コンクリート製が考えられたが、搬入方法、施工性、工期などを比較 検討しコンクリート製ケーソン方式を選択した。比較表を表ー 1 に示す。

今回のケーソンは重量が大きいため、吊上げ時に、躯体コンクリートに過大な荷重が作用し、吊上げ部の局部 的な破塤も懸念される。また破塤に至らなくても破壊荷重に達するまでに種々のひびわれの発生することが西堀 らの実験 ${ }^{2} て ゙$ 報告されており、吊上げ時の応力状態については十分検討する必要がある。

$$
\text { 表-1 ケーソンタイプ比較表 }
$$

\begin{tabular}{|c|c|c|}
\hline & 鎆製ケーソン方式 & コンクリート製ケーソン方式 \\
\hline 施工順序 & 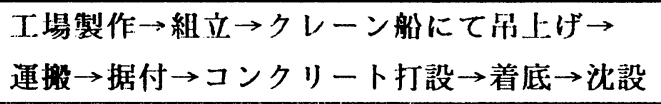 & $\begin{array}{l}\text { 陸上構築 } \rightarrow \text { 大型クレーン船にて吊上げ } \rightarrow \text { 運搬 } \\
\rightarrow \text { 据付 } \rightarrow \text { 着底 } \rightarrow \text { 沈設 }\end{array}$ \\
\hline 使用クレー船 & $1,050 \mathrm{t}$ 吊 & $4,100 \mathrm{t}$ 吊 \\
\hline 施 工 & $\begin{array}{l}\text { ・鋼製で重量も } 220 \mathrm{t} \text { と軽く、吊上げ時の } \\
\text { 問題は少ない。 } \\
\text { ・据付〜着底間は浮遊状態であり、波浪に対 } \\
\text { して不安定である。 }\end{array}$ & $\begin{array}{l}\text { ・コンクリート製で重量も } 3,200 \mathrm{t} \text { と重 } \\
\text { く吊上げ時の検討が必要である。 } \\
\text { ・浮遊状態とならないので、波浪の影響を受 } \\
\text { けにくい。 }\end{array}$ \\
\hline $\begin{array}{ll}\text { I } & \text { 期 } \\
\text { (海 } & \text { 上) }\end{array}$ & 16. 5 力月 & 14. 0 力月 \\
\hline & $\begin{array}{c}\text { ・央績は最も多いが、海上での施工期問が長 } \\
\text { く、また工費も割高である。 } \\
\triangle \\
\triangle\end{array}$ & $\begin{array}{l}\text { ・海上での施工期間が短く、最も経済的であ } \\
\text { る。 } \\
\qquad\end{array}$ \\
\hline
\end{tabular}


3. 3 ケーソン吊上げ檢討

陸上で製作したコンクリート製ケーソンの吊曳航（写真ー 1 参照）を行うにあたって、重量が約 $3,200 \mathrm{t}$ と非常に大きい事により発生する問题として下記項目が考えられ、以下に檢討内容を記す。

(1)設計荷重の決定

(2)吊筋形式の選択

(3)吊上げ時におけるコンクリートひびわれの楧討

(1)設計荷重の決定

最大吊上げ能力 $4,100 \mathrm{t}$ の国内最大のフローティングクレーンを使用したとき、実際の吊上げ可能重量は、

$(4,100 \mathrm{t}-200 \mathrm{t}) / 1.15=3,300 \mathrm{t}$

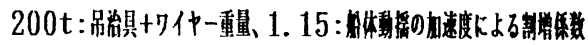

となり、ケーソン総重量は上記重量以下に抑えることとした。吊筋の設計荷重を決定する際、計算上の理論荷 重に対して余裕を見込むための安全率を設定する必要がある。一方、吊筋 1 本当りの平均荷重と各吊筋に作用す る負担荷重との此を不均等係数という。一般に各吊筋の負担荷重は、吊点数が多くなればなる程、図ー 3 に示す (1)フック部分(2)イコライザー部分(3)吊天秤部分等ワイヤーの接触する部分の抵抗にバラッキが生じるため、不均 等となりやすい。また吊史航中の起重機船の摇れによって、各吊筋には動的荷重が生じ不均等となる。

過去数例の大型ケーソン吊上げ実績および設計指針を調查したところ、不均等俰数は表一 2 に示すように 1 . 56 ～2．5となっている。吊筋の設計荷重の決定に必要な安全率は、不均等係数を考慮して決めるが、今回の 場合、表一 2 の値を参考に、さらに吊点数が 40 点と多いことを儢して、不均等係数（安全率）を 2.0 とし た。

今回の吊筋の理論荷重は、構造上重心位置の偏心によ り表ー 3 に示すように不均等となる（平均値：79.8 t）。 したがって、吊筋の設計荷重は、表-3に示す理論荷重 の最大值 $88.7 \mathrm{t}$ （吊筋番号 6) を基にして $\mathrm{w}_{\mathrm{d}}=$ $180 \mathrm{t}(>88.7 \mathrm{t} \times 2.0)$ とした。
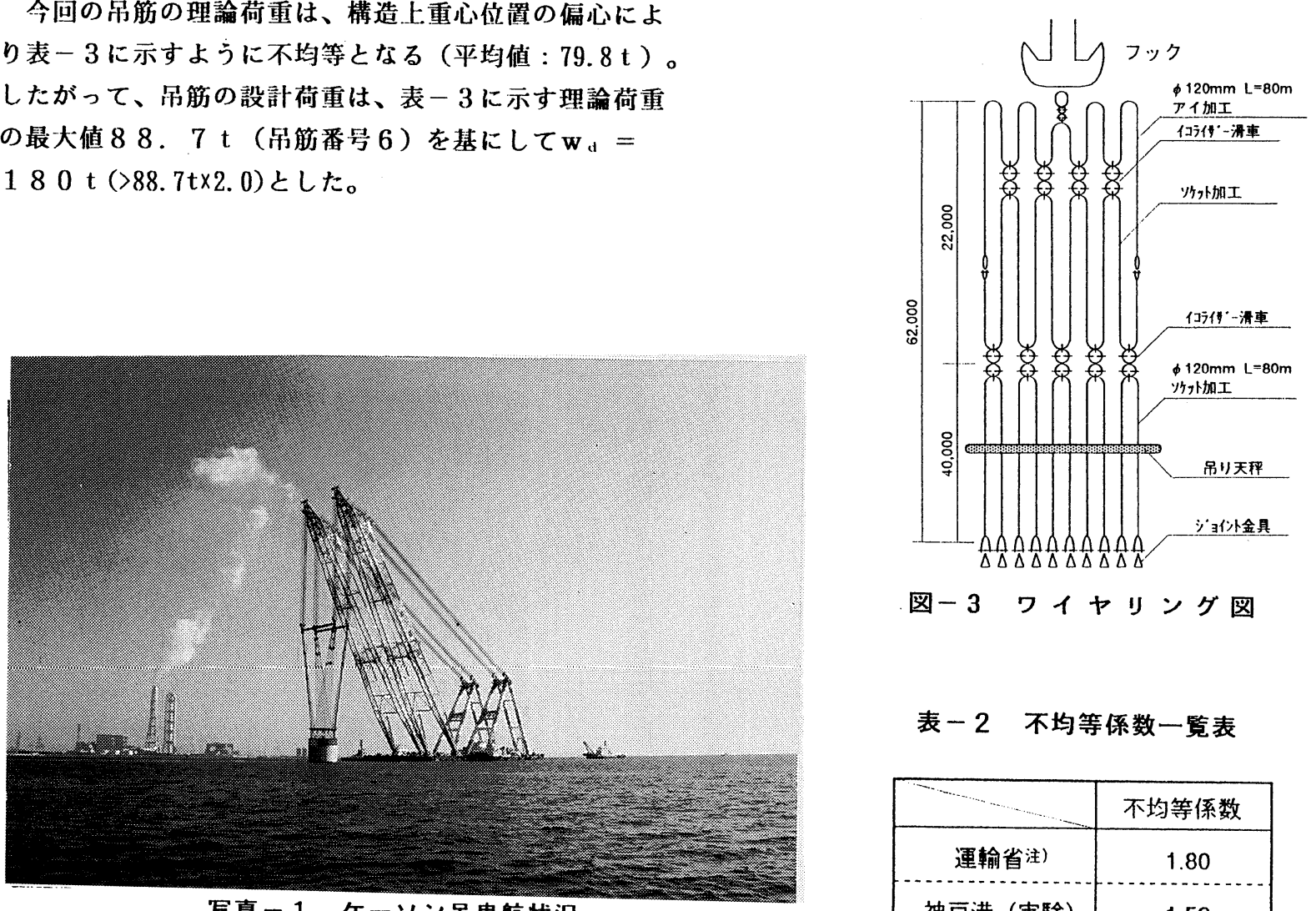

図ー3 ワイヤリング図

表 -2 不均等係数一覧表

\begin{tabular}{|c|c|}
\hline & 不均等係数 \\
\hline 運输省注 $)$ & 1.80 \\
\hdashline 神戸港 (実験) & 1.56 \\
\hline 岩大橋 (実績) & 2.50 \\
\hline
\end{tabular}

注）港湾の施設の技術上の基準・同解説より

表ー3 重心位置の偏心による各吊筋の理諭荷重

\begin{tabular}{|c|c|c|c|c|c|c|c|c|c|c|c|c|c|c|c|c|c|c|c|c|}
\hline 吊筋番号 & 1 & 2 & 3 & 4 & 5 & 6 & 7 & 8 & 9 & 10 & 11 & 12 & 13 & 14 & 15 & 16 & 17 & 18 & 19 & 20 \\
\hline 理論荷重 (t) & 80.0 & 82.9 & 85.4 & 87.4 & 88.5 & 88.7 & 88.5 & 87.4 & 85.4 & 82.9 & 80.0 & 77.1 & 74.3 & 72.1 & 70.5 & 69.8 & 70.5 & 72.1 & 74.3 & 77.1 \\
\hline
\end{tabular}


(2)吊筋形式の選択

コンクリートケーソンを吊上げる吊筋としては表－4に示すような形式がある。今回の設計荷重条件、信頼性 等から、図ー4に示す支圧板型式を採用し、吊筋径を既製品の最大径のものを使用して、吊筋数で 40 点が可能 となった。吊筇は等間隔に配置し、吊上げ時の荷重は嫩力ばらつきの無いように、全支圧板の高さおよび吊筋の メガネ部分の高さが一定になるよう、組立用架台を設け吊筋と支正板を設置した。

\section{表一 4 吊形式比较一覧表}

\begin{tabular}{|c|c|c|c|}
\hline & U型型式 & ツリダック型式 & 支任板型式 \\
\hline 略图 & $-\int \sqrt{\frac{1}{2}}$ & 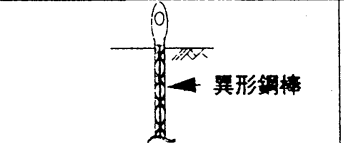 & $\int_{\text {支板 }}^{0}$ \\
\hline thx & U型に加工した丸 $(S S 400)$ & 舜强力異形 & 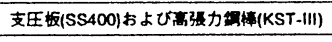 \\
\hline 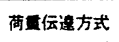 & 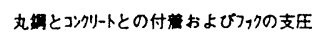 & 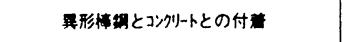 & 支圷板上部に作用する支圷力 \\
\hline 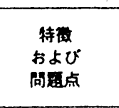 & 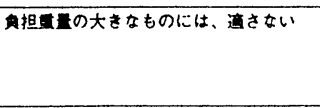 & 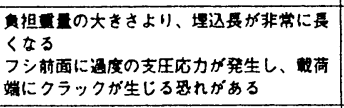 & 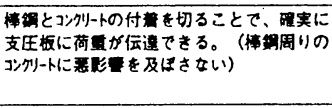 \\
\hline 要 百 & $><$ & 3 & (C) \\
\hline
\end{tabular}

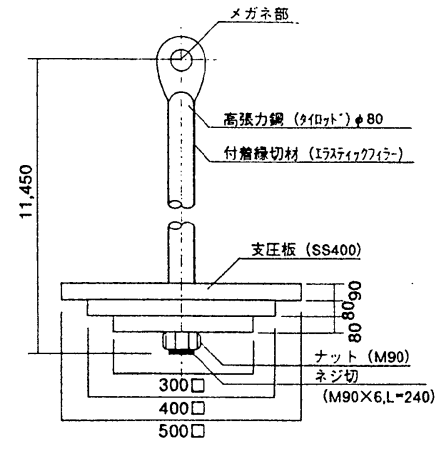

図ー4 吊筋および支王板図

(3)吊上げ時におけるコンクリートひびわれの検討

吊上げ時には、支王板付近に多大な応力集中が考えられる。そこで、応力解析を三次元有限要素法（A B A Q US）を用いて行った。図一 5 ・6に解析に用いた荷重条件およびメッシュ図を示す。

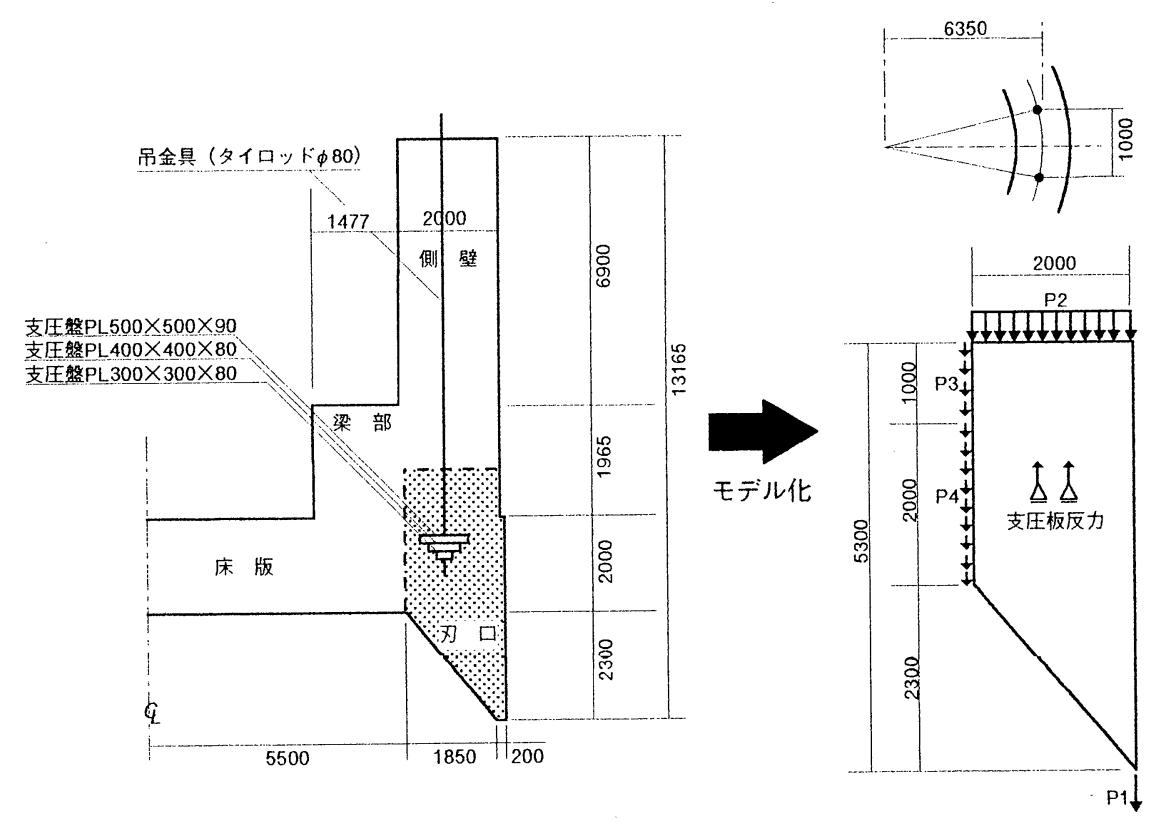

図ー 5 解析モデルおよび荷重条件

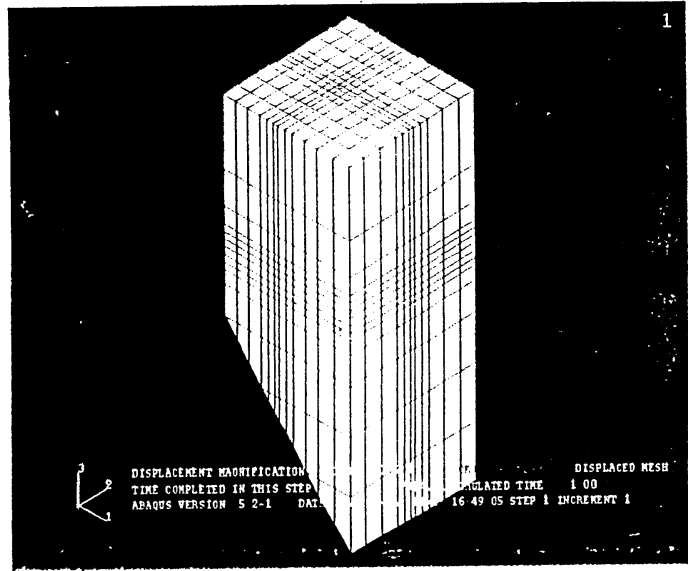

図-6メッ シ

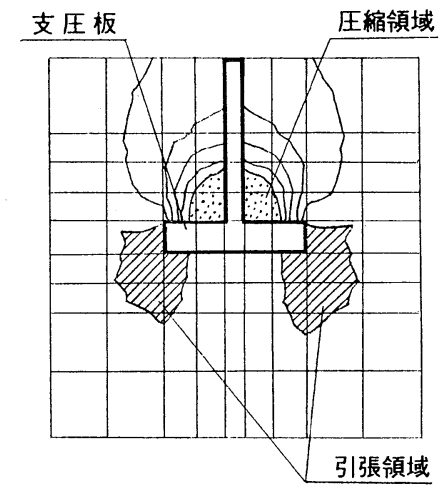

図-7 支圧板周辺の応力分布 $-366-$
部材諸元

ב設翼弾性係数 $\mathrm{E}=2.35 \times 10^{6} \mathrm{tt} / \mathrm{m}^{2}$ ポアソン比 $v=0.2$

弾性係数 $E=2.1 \times 10^{7} \mathrm{tt} / \mathrm{m}^{2}$ ポアソン比 $v=0.3$

P1:邓口自重

P2:側壁自重および側壁天端荷重 $\mathrm{P} 3$ 燃部自重

P4:床版自重および床版上荷重

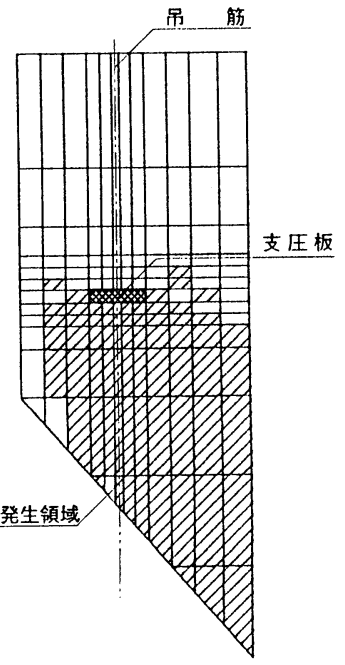

図-8 引張応力発生領域 
结力解析の結果、図-7・8に示すように支圧板上部夕イロット周辺に多大な支代応力、また下部には引張り 忘力の発生が確認された。さらに半径・円周方向にも、支圧板周包には引張り応力が発生することも明らかにな った。躯体コンクリートの許容引張り応力度 $2.5 \mathrm{kgf} / \mathrm{cm}^{2}$ に対し、ここでは、支殴板周辺にクラックを発生させ ないよう $1.0 \mathrm{kgf} / \mathrm{cm}^{2}$ として、それを越える引張り応力が発生する部位に補強筋を眍するものとした。

躯体側壁は一様な壁厚の鉄筋コンクリートではなく、トンネルが貫入してくる部分は鉄板で補強した開口部に 発泡モルタルを充填した構造となっている。このため、ケーソンの一部に用性が低く、重量の整い部分が存在し、 吊上げ時に荷重の偏心による応力分布の著しい偏りが考えられた。そこで、開口部を含めた侧壁および床版の応 力解析を図ー9に示す解析モデルよび荷重条件で実施することとした。図ー10にメッシュ割りを示す。

図ー11の解析結果を見ると、侧壁上部（1)-(1)断面）には円周方向に若干の引張応力（最大 : $0.39 \mathrm{kgf} / \mathrm{cm}^{2}$ ) が発生するが、許容応力度内に入っている。また、その他の箇所では侧壁下部（(2)一(2)断面）に代表されるよう に、压縮応力（最大：0.63kgf/ $\mathrm{cm}^{2}$ ）が大半で値も小さく問題ない事が確認されたので補強は行わなかった。 3.4 吊上げ時の計測結果

ケーソン吊上げ時の安全性を確認するために、図ー12に示すように計 40 本の吊筋のうち 20 本に吊筋轴力計 を設置し、コンクリート有効纯力計を 4 点および躯体姿勢を計列する㑯斜計を 2 点それぞれ設置し测定した。な おコンクリート有効纫力計は、クラックの最も生じやすい箇所のみ設置した。

吊上げ前日および直前に試験吊を行い、総重量の 30 0 80\%と段陼的（10\%刻み）に荷重を負荷し、各計 测値に巽常がないことを確認した後、吊上げを実施した。なお史航中は躯体の安定を計るため、ケーソンの一部 を水浸 (約 $5 \mathrm{~m})$ させた。

(1) 吊筋軸力について

最大理論荷重が作用する吊筋番号 6 におりる吊筋軸力は図一13に示すように地切後に最大値 $107 \mathrm{t}$ を示し、 これから不均等係数は 1.33 となった。また、吊筋番号 1 ・2 の軸力はケーソンを所定の場所に曳航後、海面 上に吊上げた直後にそれぞれ $105 \mathrm{t}$ と $130 \mathrm{t}$ を示し、それぞれ不均等係数は 1.31 、1．63 となり、設 計值 $\mathrm{f}=2$ ．0党下まわっていることが確認できた。

（2）躯体コンクリート㐫力について

図一14に示す躯体側壁部に発生した応力の時間的変化を見ると、躯体側壁部には図-11（2)-(2)）に示す解析 結果の通り、测定筒所では引張成力の発生は認められず、吊曳航、据付中を通して一様に压縮応力が作用してい たことがわかる。また、地切り〜据付時、外壁部に注意して目視による観察を行ったが、测定箇所以外において もクラックの発見は全く見られなかった。

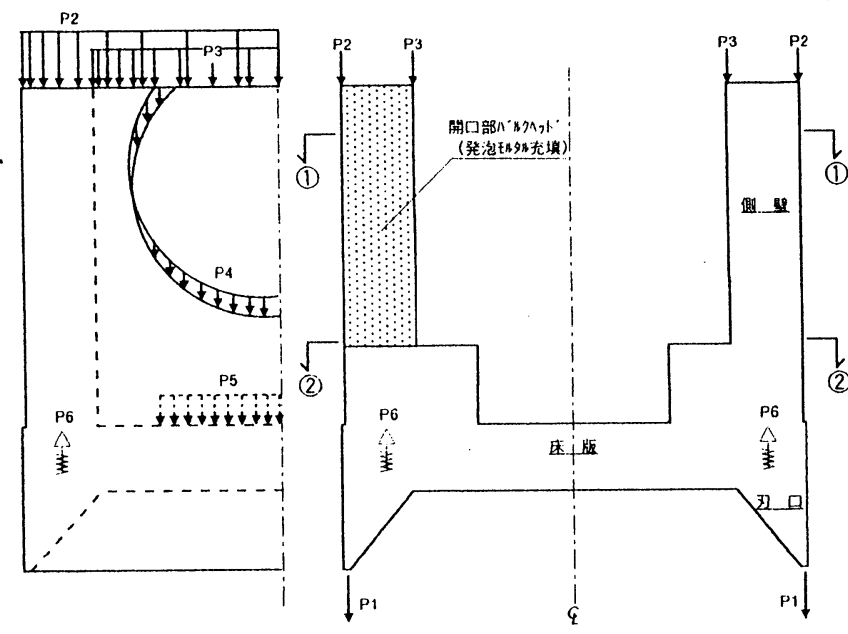

図ー9 解析モテルおよび荷重条件

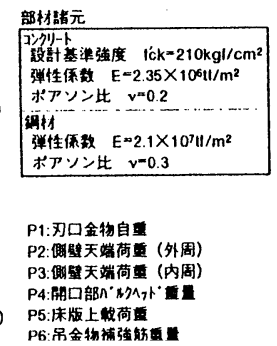

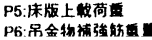

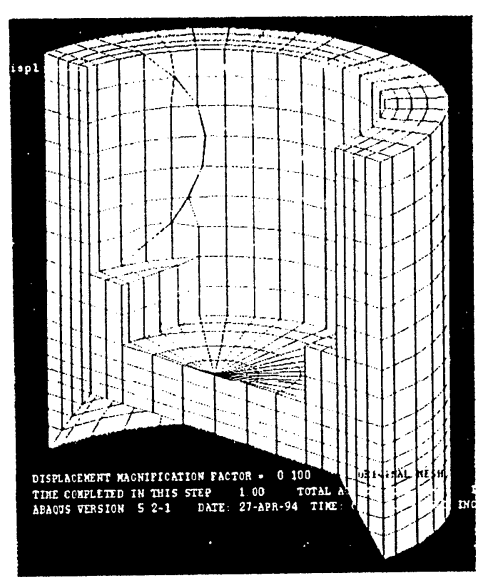

図-10×ッシ
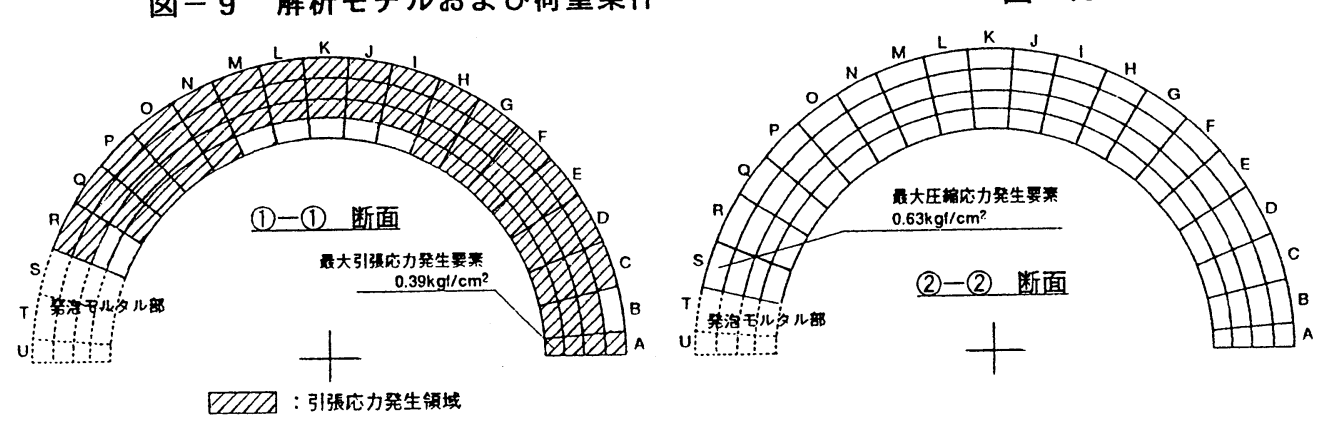

図一 11 横断面応力分布 

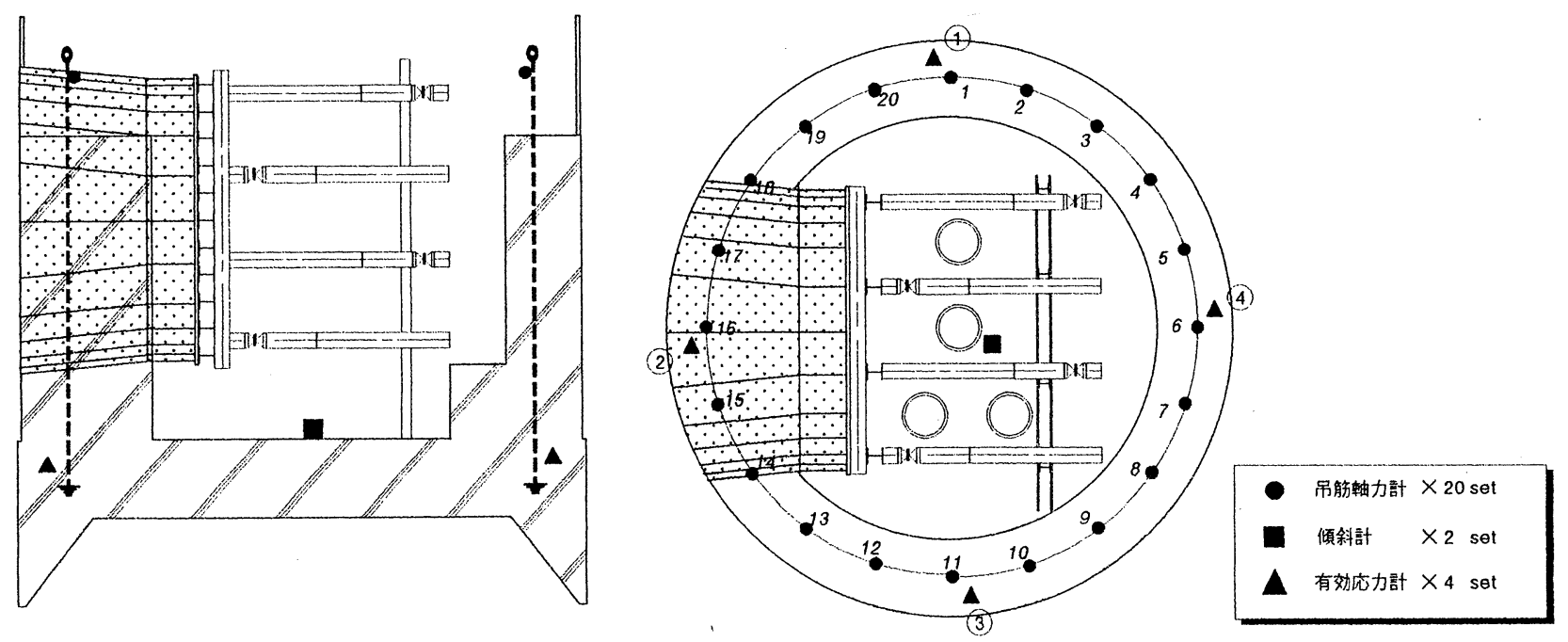

図-12 計 湘 器 配 置 図

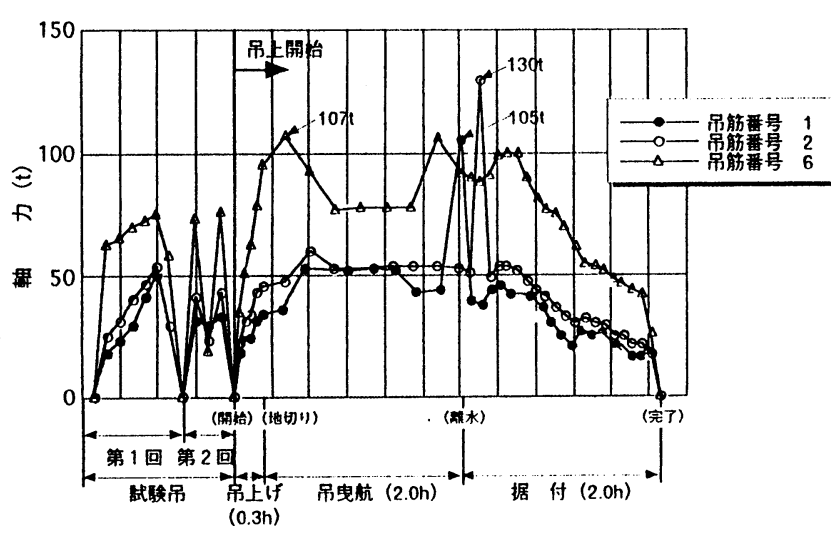

図-13 吊筋軸力の時間的変化

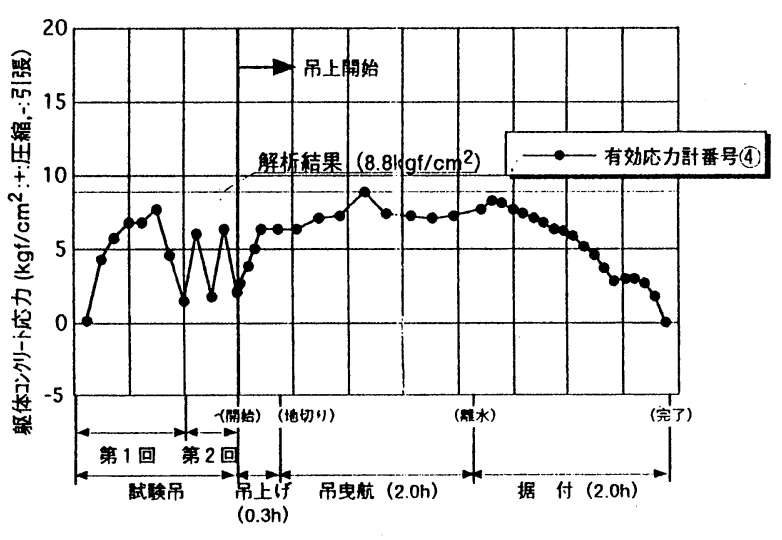

図-14 躯体コンクリート応力の時間的変化

\section{4.おわりに}

施工実績の少ない工事であったが、上記のような諸検討、対策を実施した結果、無事放水口を設置することが できた。

\section{参考文献}

1) 日本港湾協会 : 港滦の施設の技術上の基準・同解説、 1989

2)西䏱忠信、浦汇恭知他“大型ケーソンの吊筋の力学的性状について”第 29 回土木学会年次学術講演会概要 集、(1974)

3) 西场忠信、飯島炤美他“太径丸鎆を用いた吊筋の研究”第 30 回土木学会年次学術講演会概要集、（1975） 